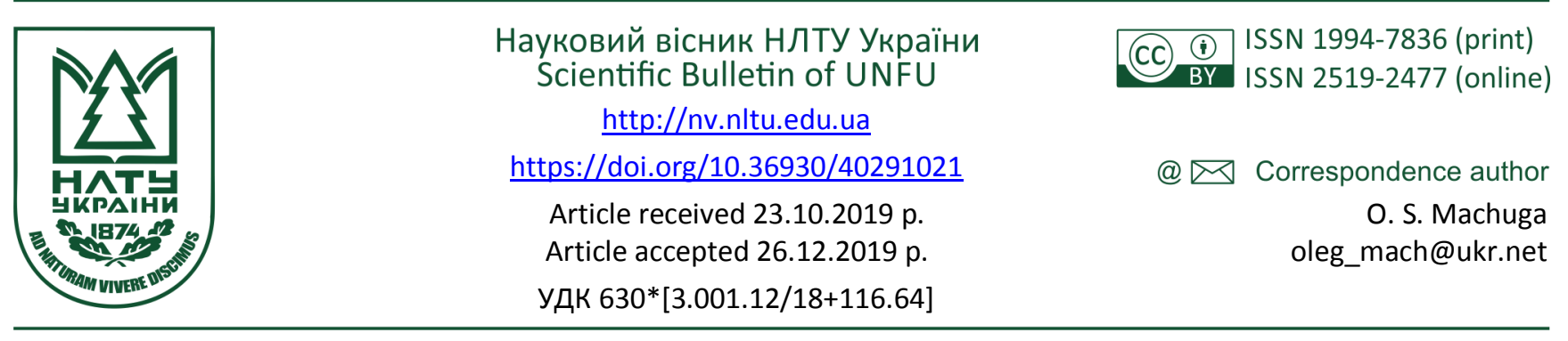

O. С. Мачуга

Національний лісотехнічний університет Украӥни, м. Львів, Украӥна

\title{
РОЗВИТОК НАУКОВИХ ЗАСАД ЕНЕРГЕТИЧНОГО ПІДХОДУ У ЛІСОТЕХНІЧНІЙ ОСВІТІ
}

Взаємодія робочих органів машин і обладнання для лісотехнічних робіт є можливою за використання енергетичного підходу. Енергетичний підхід грунтується на будуванні математичних виразів енергетичних складових - ексергії та анергії, які охоплюють основні структурно-реологічні та фізико-механічні особливості розглядуваних об'єктів. Дослідження проведено шляхом будування варіаційних нерівностей стосовно цих складових, із яких отримано низку важливих для техніки результатів щодо взаємодії машин із робочим середовищем, зокрема - процесів зношення деталей та інструменту, колієутворення, розмивання берегоукріплень тощо. Розглянуто енергетичний баланс гідромеханічної системи "машини і обладнання для заготівлі та оброблення деревини - відновні та енергетичні ресурси відходів деревинозаготівлі". Встановлено, що енергетичного ресурсу відходів заготівлі деревини та гідроресурсу річкових потоків з околу деревинообробчих виробництв $є$ достатнім для енергозабезпечення технологічних процесів галузі. Опанування студентами-механіками методів і засобів енергетичного аналізу є важливим для лісотехнічної освіти з огляду на можливість вдосконалення експлуатаційних режимів машин та обладнання галузі, для відповідного розширення екологізації освітніх програм, а також для навчання фахівців-лісомеханіків для сталого розвитку.

Ключові слова: ексергія; анергія; варіаційні нерівності; енергетичний баланс; екологізація освітніх програм.

Вступ. Дослідження процесу взаємодії робочих органів машин для лісотехнічних робіт із предметом обробітку - деревиною, опорною поверхнею - грунтом, визначення тягово-зчіпних характеристик, паливної ефективності роботи машини, базуються, зазвичай, на силовому аналізі взаємодії окремих елементів (Byblyuk, 2004). Попри це фізичний стан будь-якої системи матеріальних тіл визначається не стільки силовим контактом її окремих складників, скільки структурою та обсягом енергії, точніше - енергетичного ресурсу розглядуваної системи, здатністю енергії до трансформацій (Jakhno, \& Machuga, 2017). Повною мірою це стосується системи "машина для лісотехнічних робіт - робоче середовище". Застосування енергетичного підходу до вивчення поведінки такої системи дає змогу будувати адекватний, порівняно із силовим підходом, фізичні та математичні моделі досліджуваних об'єктів та отримувати уточнені розв'язки задач, які виникають під час аналізу згаданої системи. Навики застосування енергетичного підходу для аналізу та проектування лісових машин засвоюються студентами, зокрема освітньої програми "машини та обладнання лісового господарства". Це дає змогу не тільки опановувати ще одну методологію проектування елементів конструкцій машин та обладнання, але й усвідомлювати місце енергетичного балансу в екологізації багатьох виробничих процесів (Byblyuk, Styranivsky, \& Machuga, 2013).
Матеріали і методи. Методологія застосування енергетичного підходу у практиці лісотехнічної освіти грунтується на усвідомленні важливості аналізу досліджуваного об'єкта 3 енергетичних позицій. Насамперед - основні фундаментальні закони природи, перший та другий закони термодинаміки, сформульовано власне для енергії будь-якого об'єкта. Перший закон термодинаміки - закон збереження енергії - встановлює незмінність енергетичного ресурсу системи матеріальних об'єктів, які можуть бути формалізованими моделями системи "машина для лісотехнічних робіт - робоче середовище". Другий закон термодинаміки встановлює напрям перебігу фізичних явищ та їх незворотність у реальних процесах. Власне це істотно відрізняє енергетичний підхід від силового, за якого результати досліджень можуть характеризувати процес як цілковито зворотний. Тому повсюдно прийнято $(\operatorname{Sedov}, 1976)$ вважати енергетичний підхід первинним відносно силового, а енергетичні характеристики процесу - головними параметрами стану системи тіл, із яких можливо визначати звичні для сприйняття сили, напруження, швидкості, деформації тощо. Загальне відношення параметрів стану за силового та енергетичного підходів під час формування фізичної та математичної моделей об'єкта дослідження, розв'язування задач практики, вказано на схемі (рис. 1), сформованій на підставі систематизації, викладеній у (Machuga, \& Jakhno, 2018).

\section{Інформація про авторів:}

Мачуга Олег Степанович, канд. фіз.-мат. наук, доцент, кафедра лісових машин та гідравліки. Email: oleg_mach@ukr.net; https://orcid.org/0000-0002-9151-8854

Цитування за ДСтУ: Мачуга О. С. Розвиток наукових засад енергетичного підходу у лісотехнічній освіті. Науковий вісник НЛту України. 2019, т. 29, № 10. С. 103-108.

Citation APA: Machuga, O. S. (2019). The development of energy approach scientific basis in the forestry education. Scientific Bulletin of UNFU, 29(10), 103-108. https://doi.org/10.36930/40291021 
Розвиток методології досліджень, яка грунтується на енергетичному підході, базується на формулюванні варіаційно-енергетичного принципу, а саме: дійсний стан чи процес, у якому перебуває матеріальний об'єкт, відрізнясться від усіх інших кінематично можливих станів чи процесів тим, щзо за дійсного стану чи процесу енергія об'єкта набуває стаціонарного (екстремального) значення. Енергетичний ресурс (енергія) такого об'єкта, записаний з урахуванням структурних особливостей деформування складників цього об'єкта, фізикомеханічних характеристик та умов контактної взаємодії окремих компонент об'єкта між собою та із зовнішніми контактними і деформаційними чинниками, є функціоналом енергії системи $E$. Математичний запис сформульованого вище варіаційного принципу має такий вигляд:

$$
\delta E=0 .
$$

Із рівняння (1) можливо отримати всі характеристики досліджуваного об'єкта, які є важливими для подальших проектувальних розрахунків та визначення експлуатаційних режимів машин та виробничих процесів за їх участі. Важливим у методологічному плані $є$ встановлення найвагоміших для досліджування об'єкта пара- метрів стану, вираження енергетичного ресурсу $E$ через ці параметри та будування розв'язку рівняння (1).

Однак у реальних процесах, супроводжуваних дисипаційними явищами, зокрема - трансформацією пружної енергії у теплову та поверхневу, рівняння (1) трансформується у варіаційну нерівність (Kinderlerer, \& Stampakkia, 1983):

$$
\delta(E x-A n) \leq 0,
$$

у якій $E x, A n$ - відповідно ексергія та анергія - складові енергетичного ресурсу (Baer, 1968). Варіаційна нерівність (2) є основним відношенням для аналізу будь-якої механічної системи із вираженими дисипаційними властивостями, зокрема системи "машина для лісотехнічних робіт - робоче середовище", в якому можуть відбуватись незворотні зміни, пов'язані із перебігом технологічних процесів, наприклад - зношення деталей машин, інструментів, колієутворення, розмивання берегової лінії, енергозабезпечення виробничих процесів та низка інших процесів (Jakhno, \& Machuga, 2016). Ексергійний аналіз технологічних процесів, виконуваних мобільними машинами, викладено у працях (Jakhno, \& Pastushenko, 2004).

Процес взаємодії матеріальних об'єктів

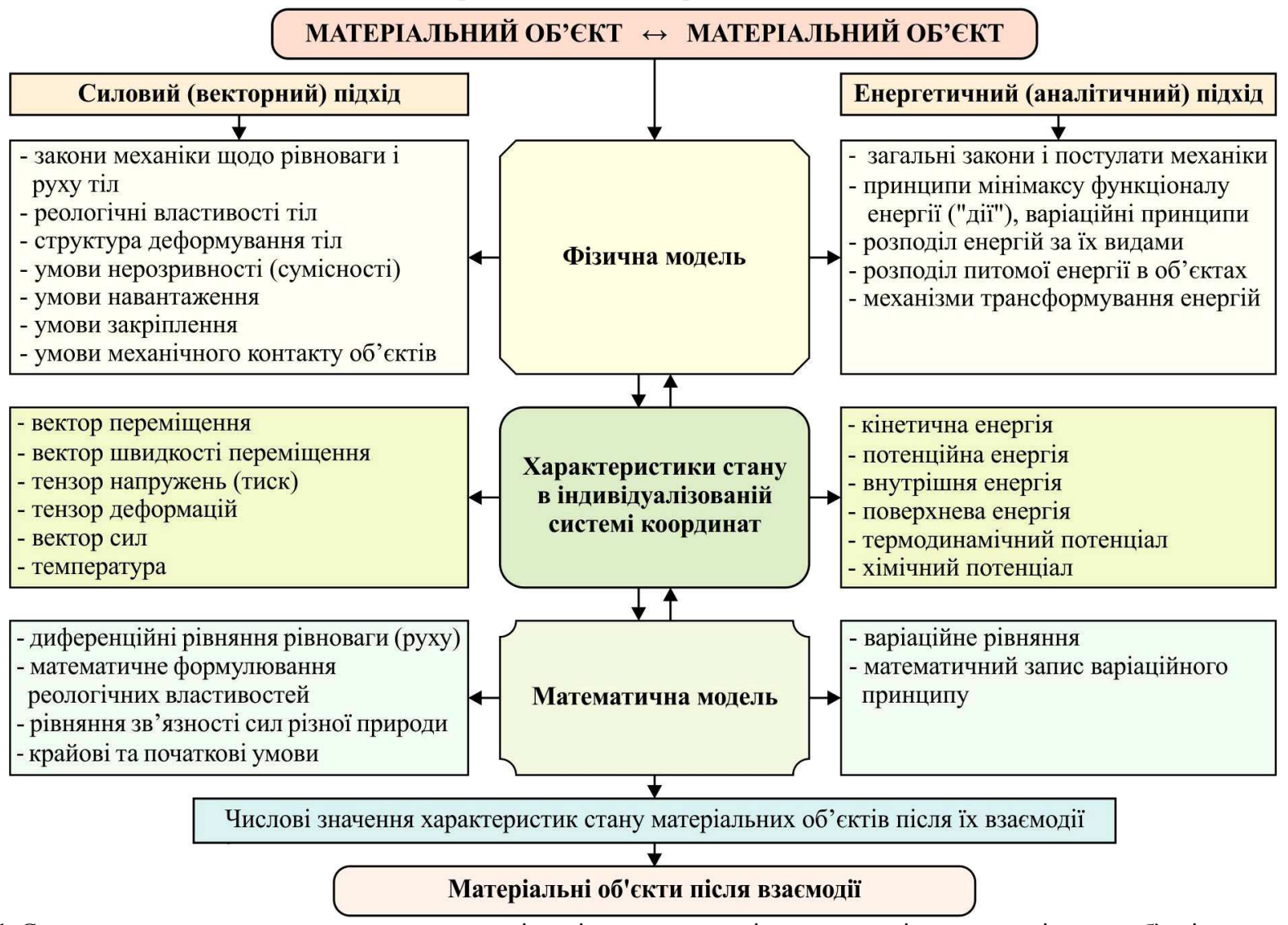

Рис. 1. Структурна схема силового та енергетичного підходів у моделюванні та визначенні стану матеріальних об'єктів

Оволодіння методологією енергетичного підходу щодо дослідження таких процесів і явищ вбачається вагомим для навчання студентів-механіків не тільки з огляду на розширення їх фахового готування, але й для формування екологізації навчального процесу та світосприйняття, що викладено нижче.

Результати дослідження. Наведена вище методологія є прийнятною для дослідження граничних станів будь-яких механічних систем. Нижче викладено результати дослідження енергетичного балансу системи "машини і обладнання для заготівлі та оброблення деревини - відновні та енергетичні ресурси відходів деревинозаготівлі", що є важливим для екологізації сучасної лісотехнічної освіти. Тому розглянемо енергозабезпечення технологічних процесів лісозаготівлі, транспортування та первинного перероблення деревини, яке базується на використанні рідких палив та електроенергії, що відповідним чином впливає на вартість продукції та величину теплових викидів у навколишнє середовище. Інтегроване використання енергії відновних 
джерел уможливить часткову або повну відмову від класичних джерел енергії у лісовій галузі. Використання енергії відновних джерел може привести до позитивних екологічних наслідків. Зокрема, використання гідроенергії, що пов'язане із зведенням гідротехнічних споруд на гірських річках, приведе до збільшення зарегульованості їх стоку та відповідного зниження негативних наслідків повеней і паводків. Використання відходів заготівлі деревини та пошкодженої й некондиційної деревини як біопалива не впливатиме на зміну фактичного теплового балансу екосистеми, однак призведе до зменшення кількості осередків розвитку хвороботворчих організмів.

Цей виклад присвячено аналізуванню умов балансу між сумарним енергетичним ресурсом різнорідних відновних джерел та енергоспоживанням деяких технологічних процесів лісозаготівлі. У досліджуваній гідромеханічній системі "машини і обладнання для заготівлі та оброблення деревини - відновні та енергетичні ресурси відходів деревинозаготівлі" ресурс відновних джерел збігається з ексергією, а енергоспоживання технологічних процесів - 3 анергією. Отже, проблематика інтегрованого енергозабезпечення технологічних процесів лісозаготівлі зводиться до вивчення ексерго-анергійного балансу цієї системи.

Ця робота є підсумком низки вислідів, зокрема (Byblyuk jun, \& Machuga, 2010) у таких напрямах. Типізовано види відновних джерел енергії доступні для використання у лісозаготівлі з огляду на їх економічну доцільність. Проаналізовано технологічні процеси лісозаготівлі, транспортування та первинного перероблення деревини, для яких можливе використання механічної та теплової енергії із відновних джерел. Визначено по- рівняльну енергоємність відходів лісозаготівлі, сонячної енергії та гідроресурсів. Запропоновано принципову схему інтегрованого використання енергії відновних джерел у технологічних процесах заготівлі деревини, їі транспортування та первинного оброблення. Виконано порівняльний аналіз витрат енергії для виконання виробничих процесів із використанням механічного, гідро- та пневмоприводу. Розроблено принципову схему установки для енергозабезпечення 3 відновних джерел виробничих процесів лісозаготівлі, транспортування та первинного перероблення деревини та охарактеризовано методику іiї проектування із врахуванням специфіки технологічного процесу, який вона забезпечує енергією. Потреба використання енергії відновних джерел виникає $з$ потреби збалансування енергетичних витрат iз сумою енергії сонця та геотермальної енергії. Інтенсивне вивільнення закумульованої енергії (вугілля, природний газ, нафта тощо), використовуваної у промисловості та побуті, призводить до пришвидшення процесу глобального потепління.

Для енергетичного аналізу проблем, пов'язаних із глобальним потеплінням, розглянемо енергетичний баланс Землі. На рис. 2 ( $a$ ) подано схему теплового балансу в період формування енергетичних запасів. Рівноважний стан описується відношенням:

$$
E_{C}+E_{\Gamma}=E_{\text {ВІдБ }}+E_{\text {ВИПР }}+E_{H},
$$

де: $E_{C}-$ енергія сонячного випромінювання; $E_{\Gamma}-$ геотермальна енергія; $E_{\text {Випр }}, E_{\text {ВІдь }}$ - енергія, що випромінюється та (або) відбивається у навколишнє середовище; $E_{H}-$ енергія, що накопичується у вигляді горючих копалин.

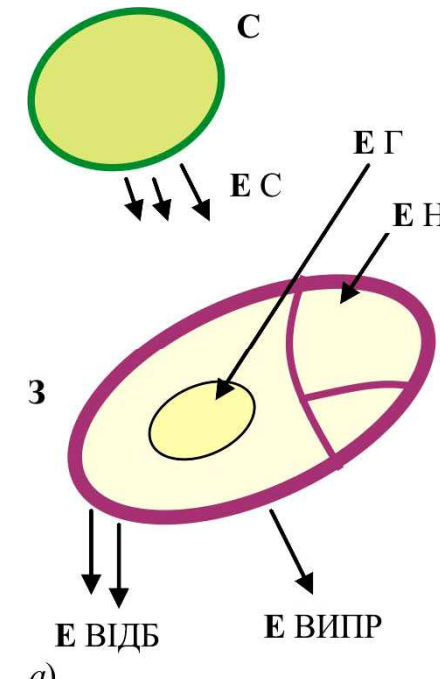

a)

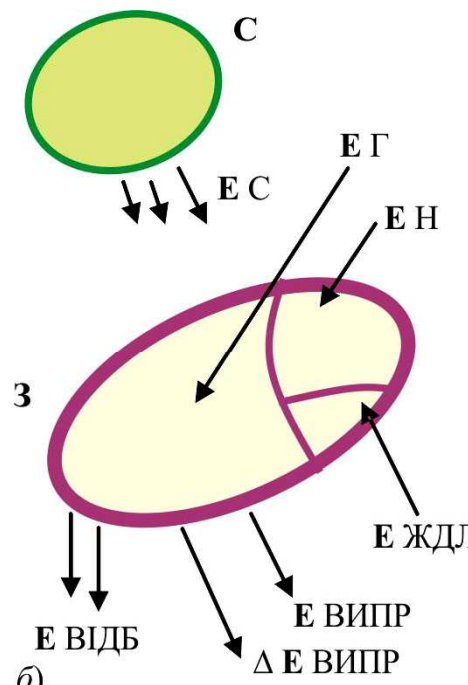

б)

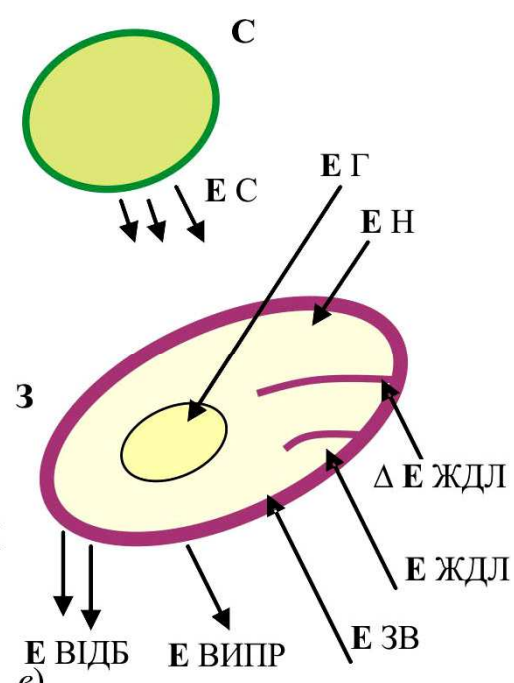

B)

Рис. 2. Енергетичний баланс: a - первинний, б - з появою технологічних процесів, в - у період вивільнення надлишкової теплової енергії; 3 - Земля, С - Сонце

Розвиток промисловості супроводжувався заміною використання м'язевої енергії енергією теплових машин. Унаслідок роботи таких машин вивільнюється теплова енергія - енергія життєдіяльності людини $E_{\text {жлл }}$, джерело якої - вивільнення попередньо накопичених копалин. Енергетичний баланс (див. рис. 2,б) збе-

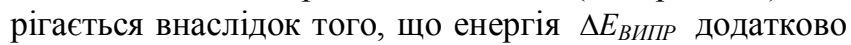
випромінюється в навколишнє середовище:

$$
E_{C}+E_{\Gamma}+E_{\text {жДЛ }}=E_{\text {ВІДБ }}+E_{\text {ВИПР }}+E_{H}+\Delta E_{\text {ВИПР. }}
$$

Подальший розвиток промисловості, збільшення енергоємності виробничих процесів, зокрема - у лісозаготівлі, машинобудуванні, транспортній галузі тощо, змінює рівновагу, визначену рівнянням (4) й може призвести до незворотних змін. Схему енергетичного балансу для цього періоду подано на рис. 2,6. Визначальне енергетичне співвідношення, як це випливає 3 ексергійно-анергійного аналізу, перетворюється у таку нерівність:

$E_{C}+E_{\Gamma}+E_{\text {ждл }}+\Delta E_{\text {ЖдЛ }}+E_{3 B} \geq E_{\text {ВІДь }}+E_{\text {ВИПР }}+E_{H}+\Delta E_{\text {ВИПР }},(5)$ 
де $E_{3 в}$ - енергія зворотна випромінюванню, зумовлена наявністю "парникового ефекту". Шляхом розв'язування нерівності (5) можна прогнозувати процес підвищення температури навколишнього природного середовища. Умовою стабілізації температури є зменшення величини $\Delta E_{\text {ждл }}$ до досягнення рівноважного стану, знак нерівності у співвідношенні (5) перетвориться у знак

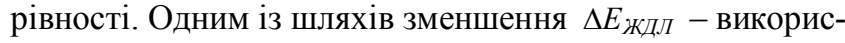
тання енергії відновних джерел у виробничих процесах, зокрема у лісозаготівлі.

Надлишкова енергія життєдіяльності людини формується у таких технологічних процесах: видобування горючих копалин, вироблення та транспортування енергоносіїв до місця їх споживання, теплові втрати під час перетворення енергоносіїв у механічну енергію та під час технологічних процесів виготовлення додаткової продукції (рис. 3). Додаткова енергія життєдіяльності людини є сумою усіх перерахованих втрат:

$$
\Delta E_{\text {Ждл }}=E_{1}+E_{2}+E_{T P}+E_{B} .
$$

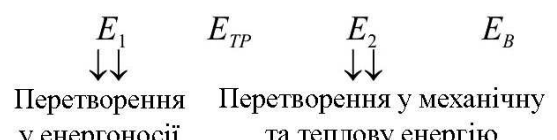

у енергоносіі та теплову енергію

\begin{tabular}{|c|c|c|}
\hline $\begin{array}{l}\text { Горючі } \\
\text { копалини: } \\
\text { вугілля } \\
\text { нафта } \\
\text { газ } \\
\text { сланці }\end{array}$ & $\begin{array}{l}\text { Енергоносії: } \\
\text { електроенегія } \\
\text { рідке паливо } \\
\text { газ } \\
\text { ядерне паливо }\end{array}$ & $\begin{array}{l}\text { Продукція: } \\
\text { лісозаготівлі } \\
\text { металообробки } \\
\text { машинобудування } \\
\text { IT } \\
\text { споживча }\end{array}$ \\
\hline
\end{tabular}

Рис. 3. Схема формування енергетичних втрат під час перетворення горючих копалин у додаткову продукцію: $E_{1}-$ енергетичні втрати під час перетворення горючих копалин у енергоносії; $E_{T P}$ - енергетичні втрати, зумовлені необхідністю транспортування енергоносіїв до місця їх споживання; $E_{2}$ - енергетичні втрати під час виробляння механічної енергії із енергоносіїв - для технологічних потреб; $E_{B}-$ теплові втрати у виробничих процесах перероблення сировини у продукцію.

Інтегроване використання різнорідних локальних відновних джерел енергії може призвести до зменшення тепловиділень на усіх етапах енергозабезпечення виробничих процесів, зокрема й у лісовій галузі. Важливим $є$ й відповідне здешевлення продукції. 3 огляду на це актуальною проблемою є модернізація виробничих процесів за максимально можливого використання енергії відновних джерел. Для прикладу, переорієнтування лісозаготівельної та лісопереробної промисловості Косівського та Верховинського районів Івано-Франківської обл. на поновлювані джерела енергії та пряму передачу енергії від джерела до споживача, може забезпечити річне скорочення теплових викидів 210 млрд ккал тільки завдяки економії електроенергії, а використання лише $10 \%$ гідропотенціалу Черемошу може забезпечити потреби енергії у цих районах.

Попередньо доведено (Byblyuk jun, \& Machuga, 2010), що енергоресурсів 3 відновних джерел $\epsilon$ достатньо для забезпечення виробничих потреб процесів лісозаготівлі, транспортування та первинного перероблення деревини; існує можливість переобладнання технічних засобів лісової галузі для використання їх iз приводом, що живиться енергією відновних джерел навіть за незначної ефективності енергогенеруючого устатковання.
Висновки. У роботі обгрунтовано та розвинуто енергетичний підхід дослідження умов балансу широкого класу механічних об'єктів. Загальною методологією такого підходу є будування варіаційної нерівності стосовно складових енергетичного ресурсу системи ексергії та анергії. Використання енергетичного підходу дає змогу адекватніше, порівняно із силовим підходом визначати експлуатаційні характеристики машин i механізмів, застосовуваних, зокрема, у лісовому господарстві.

Розглянуто енергетичний баланс системи "машини i обладнання для заготівлі та оброблення деревини - відновні та енергетичні ресурси відходів деревинозаготівлі", детально проаналізовано величини таких ресурсів і зіставлено їх із технологічними потребами. Оскільки вагомою складовою вартості заготовлених деревинних матеріалів є вартість енергоносіїв, а процеси заготівлі деревини, іiі транспортування та первинного перероблення локалізуються у безпосередній близькості до доступних відновних джерел енергії - відходів заготівлі та перероблення деревини, а також - гідроресурсів, доцільно у розглядуваних технологічних процесах використовувати власне такі джерела енергії, потенціал яких, як встановлено за допомогою ексергійно-анергійного аналізу, значно перевищує енергетичні потреби технологій процесів.

Опанування студентами-механіками методів і засобів енергетичного аналізу є важливим для лісотехнічної освіти $з$ огляду на можливість вдосконалення експлуатаційних режимів машин та обладнання галузі, а також для відповідного розширення екологізації освітніх програм.

\section{References}

Baer, G. (1968). Energy, exergy, anergy. In V. M. Brodiansky (Ed.). Energy and exergy, (pp. 12-27). Moscow: Mir. [In Russian].

Byblyuk, N. I. (2004). Forest vehicles: Theory. Lviv: Panorama. [In Ukrainian].

Byblyuk, N. I., Styranivsky, O. A., \& Machuga, O. S. (2013). Educational process ecology directions for the forest mechanics - specialists in the sustainable development. Ser. Ecology, (pp. 520-522). Vinnycia: Dilo. [In Ukrainian].

Byblyuk, N. N., \& Machuga, O. S. (2010). Some aspects energy potential of the Hutsulshchyna. Proceedings of the Shevchenko Scientific Society: Regional studies, 3, 258-266. Kosiv: Hutsulshchyna. [In Ukrainian].

Jakhno, O. M., \& Machuga, O. S. (2016). Exergy analysis and variation inequality method in some practical problems of hydro mechanical. Journal MMI KPI, Machinery, 78(3), 19-25. [In Ukrainian].

Jakhno, O. M., \& Machuga, O. S. (2017). Variational formulation of problems for structurally inhomogeneous hydro mechanical systems. Industrial hydraulics and pneumatics, 56(2), 26-33. [In Ukrainian].

Jakhno, O. M., \& Pastushenko, S. I. (2004). Base of the exergy economics. Bulletin of the Tauride Foundation, 19, 61-65. [In Ukrainian].

Kinderlerer, D., \& Stampakkia, G. (1983). Introduction to Variational Inequalities. Moscow: Mir. [In Russian].

Machuga, O. S., \& Jakhno, O. M. (2018). Application of the energy approach to the analysis of the behavior of non-idealized mechanical and hydro mechanical systems. Mechanics and Advanced Technologies, 82(1), 43-50. [In Ukrainian].

Sedov, L. I. (1976). Continuum mechanics. Moscow: Science. [In Russian]. 


\section{THE DEVELOPMENT OF ENERGY APPROACH SCIENTIFIC BASIS} IN THE FORESTRY EDUCATION

Investigation of the interaction between the machine working bodies and forestry works equipment is possible in the case of force approach application, as well as in the case of energy approach usage. It is important to teach students the methods and means of energy methodology. The energy approach is based on the construction of mathematical expressions of energy components - exergy and anergy, which cover the main structural, rheological and physical, and mechanical features of the objects under consideration. The research is carried out by constructing variational inequalities in relation to these components. From these inequalities a number of important results concerning the interaction of machines with the working environment were obtained, in particular the processes of wear and tear of parts and tools, the formation of vehicle rutting, the erosion of shore reinforcements, etc. The energy balance of the hydro mechanical system "machinery and equipment for harvesting and processing of wood - the renewable hydraulic and wood waste wastes energy resources" is also considered. The importance of such balance follows from the equilibrium of the energy resources, received by our planet from the sun, the ability to accumulate such energy in the form of combustible minerals and the release of such energy accumulation during the technological processes introduced by mankind. It was revealed that the energy resource of wood waste and hydro resources of river flows from the vicinity of wood processing enterprises is sufficient for the energy supply of technological processes in the forestry industry. The installation for energy supply of technological processes of the industry by renewable sources is offered. The method of designing such installation is substantiated. The mastery of students-mechanics in methods and tools of the energy analysis is important for forest engineering education in view of the possibility of improving the operating modes of machinery and equipment in the industry, for the corresponding expansion of the educational programs ecologization, as well as for the training of specialists - forestry mechanics for sustainable development.

Keywords: exergy; anergy variation inequalities; energy balance; educational programs ecologization. 